\title{
Characterization of hemagglutination activity of emerging Newcastle disease virus in Bangladesh
}

\author{
Helal Uddin ${ }^{1,6}$, Kamrul Islam²,3,6, Mukti Barua ${ }^{4}$, Shariful Islam ${ }^{5}$ and Abdul Ahad ${ }^{6}$
}

1. Department of Livestock Services, Ministry of Fisheries and Livestock, Government of the People's Republic of Bangladesh, Bangladesh; 2. Biosafety \& Biosecurity Consultant, One Health Epidemiology Fellow, Institute of Epidemiology, Disease Control and Research (IEDCR), Dhaka, Bangladesh; 3. Institute of Veterinary, Animal and Biomedical Sciences, Massey University, New Zealand; 4. Department of Animal Science and Nutrition, Chittagong Veterinary and Animal Sciences University, Chittagong, Bangladesh; 5. EcoHealth Alliance, New York, USA;

6. Department of Microbiology and Veterinary Public Health, Faculty of Veterinary Medicine, Chittagong Veterinary and Animal Sciences University, Chittagong, Bangladesh.

Corresponding author: Kamrul Islam, e-mail: kamruldvm13@gmail.com,

Co-authors: HU: helalcvasu49@yahoo.com, MB: mukti.barua@yahoo.com, SI: sharifdvm51@gmail.com, AA: ahadvet1969@yahoo.co.uk

Received: 21-03-2017, Revised: 02-05-2017, Published online: 06-06-2017

doi: 10.14202/IJOH.2017.28-35 How to cite this article: Uddin H, Islam K, Barua M, Islam S, Ahad A. Characterization of hemagglutination activity of emerging Newcastle disease virus in Bangladesh. Int J One Health 2017;3:28-35.

\begin{abstract}
Aim: Newcastle disease (ND) is an important viral disease for poultry caused by avian paramyxovirus which can be identified by its nature of agglutination activity with red blood cell (RBC) of different species. The study was aimed to characterize the hemagglutinating (HA) activity of ND virus (NDV) at three different temperatures using RBC of five avian species, six mammalian species, and eight different human blood groups.
\end{abstract}

Materials and Methods: The study was conducted from January to December 2014 at Chittagong Veterinary and Animal Sciences University. Five avian and six different mammalian species were selected for the study. In each species, two blood samples were collected aseptically. Eight different blood groups $\left(\mathrm{A}+, \mathrm{A}_{-}^{-}, \mathrm{B}+, \mathrm{B}^{-}, \mathrm{AB}+, \mathrm{AB}^{-}, \mathrm{O}^{+}\right.$, and $\left.\mathrm{O}^{-}\right)$were studied in human. HA test was performed using two virus strains ND lasota and field isolate of very virulent NDV (VVNDV) with mentioned species of $\mathrm{RBC}$ at chilling $\left(4^{\circ} \mathrm{C}\right)$, incubating $\left(37^{\circ} \mathrm{C}\right)$, and room temperature $\left(24^{\circ} \mathrm{C}\right)$.

Results: Avian RBC requires less time for agglutination than mammalian RBC. Incubation temperature $\left(37^{\circ} \mathrm{C}\right)$ requires lowest time and chilling temperature requires highest time for agglutination of RBC. Duck RBC requires lowest time (17.81 min) while chicken RBC needs highest (57.5 min) time for HA at incubation temperature and at chilling temperature, respectively, against ND lasota virus and with field strain. Goat RBC requires significantly higher time for HA (184.68 min) at chilling temperature than other mammalian species. Human $\mathrm{RBC}$ requires almost similar time but $\mathrm{O}+$ and $\mathrm{O}-$ blood group do not show any HA activity. Significant variation $(\mathrm{p}<0.05)$ found in quail $\mathrm{RBC}$ at incubation temperature. In mammalian species, a significant difference $(\mathrm{p}<0.05)$ has been observed in goat and horse RBC at chilling; horse and dog RBC at incubation; goat, horse, buffalo, and $\operatorname{dog} \mathrm{RBC}$ at room temperature. In human, significant variation $(\mathrm{p}<0.05)$ has been found in $\mathrm{A}^{+}, \mathrm{A}^{-}$and $\mathrm{B}-$ blood group in chilling, in $\mathrm{B}+$ blood group at incubation and $\mathrm{A}+, \mathrm{B}+, \mathrm{B}-, \mathrm{AB}^{-}$blood group at room temperature against two virus strains.

Conclusion: ND is considered as an economically significant disease which is highly contagious in nature infecting many avian species. The threat of ND outbreak to poultry industry necessitates effective control measures to reduce the burden in commercial and backyard farming in Bangladesh.

Keywords: chilling temperature, hemagglutination, incubation temperature, Newcastle disease virus, Newcastle disease virus lasota strain, very virulent Newcastle disease virus strain

\section{Introduction}

For the past five decades, production in poultry industry has documented greater changes than in any other world's livestock subsector in agricultural production. Promising trends in livestock production indicate that the global production of poultry meat and dairy will double by 2050 [1]. Poultry industry

\footnotetext{
Copyright: Uddin, et al. This article is an open access article distributed under the terms of the Creative Commons Attribution 4.0 International License (http://creativecommons.org/licenses/ by/4.0/), which permits unrestricted use, distribution, and reproduction in any medium, provided you give appropriate credit to the original author(s) and the source, provide a link to the Creative Commons license, and indicate if changes were made. The Creative Commons Public Domain Dedication waiver (http:// creativecommons.org/ publicdomain/zero/1.0/) applies to the data made available in this article, unless otherwise stated.
}

is one of the fastest emerging livestock subsectors which has the annual growing rate of around $20 \%$ in Bangladesh [2]. The industry plays a key role in the national economy by making employment. Moreover, the sector is committed to mitigate the demand of good quality protein using meat and egg in inexpensive price [3].

Newcastle disease (ND) is a highly contagious viral disease that attacks many species of domestic and wild birds, caused by ND virus (NDV) which belongs to the family Paramyxoviridae and genus, Rubulavirus [1,4-6]. Mortality may reach up to $100 \%$ in infected chicken [1]. The disease is important considering the number of animals affected each year and the huge economic impact on the poultry production industry [7]. No treatment for NDV exists, 
but the use of prophylactic vaccines and biosecurity measures reduces the likelihood of NDV outbreaks. Vaccination has been reported as the only safeguard against endemic ND [8].

NDV is an enveloped virus having two membrane proteins, the hemagglutinin-neuraminidase $(\mathrm{HN})$ protein associated with cell attachment and release, and the fusion $(\mathrm{F})$ protein mediating fusion of the viral envelope with cellular membranes [6,9]. For infectivity and pathogenicity of NDV, both HN and F glycoproteins are important for virus [10] for the production of protective antigens and virus neutralizing antibody responses [11,12]. The $\mathrm{F}$ protein has been shown to induce protective immunity to NDV in chickens. However, the birds showed lower neutralizing antibody titers, but $\mathrm{HN}$ protein has also been shown to protect birds from virulent NDV challenge and it has also been shown that monoclonal antibodies to $\mathrm{F}$ protein neutralize NDV better than monoclonal antibodies to HN protein [12].

Avian paramyxovirus serotype- 1 is a member of the Paramyxoviridae family and is the causative agent of virulent ND which is capable of infecting a wide range of avian species leading to a broad range of clinical symptoms [13]. It might have capacity to agglutinate the red blood cell (RBC) of mammalian and other birds other than chicken if they have HA protein binding receptors on the membrane of their RBCs. The HN protein is also responsible for different NDV strains to agglutinate type of RBCs [14]. However, all NDV strains agglutinate chicken RBC [15], but additionally, the lentogenic strains agglutinate mammalian RBCs $[14,15]$. Therefore, the study was aimed to characterize the hemagglutinating (HA) activity of NDV to multi-species RBC at different temperatures.

\section{Materials and Methods}

\section{Ethical approval}

The study protocol was permitted by the Ethics Committee of the Chittagong Veterinary and Animal Sciences University (CVASU), Chittagong, Bangladesh.

\section{Duration, species selection, and sample collection}

The study conducted in CVASU from January to December 2014. Five avian (chicken, duck, geese, quail, and pigeon) and six different mammalian species (cattle, buffalo, sheep, goat, horse, dog, and human) were selected for the study. From each species, two blood samples were collected using antiseptic swab, sterile syringe, and vial containing ethylenediaminetetraacetic acid as anticoagulant. Each sample was replicated for at least 2 microtiter plate means 16 times per sample. In case when human samples were collected, informed consent was attained from each of two participants. Eight different blood groups $\left(\mathrm{A}^{+}, \mathrm{A}^{-}, \mathrm{B}^{+}, \mathrm{B}^{-}, \mathrm{AB}^{+}, \mathrm{AB}^{-}, \mathrm{O}^{+}\right.$, and $\left.\mathrm{O}^{-}\right)$ were studied in human. After collection blood samples were transported to the laboratory for the preparation of $1 \%$ RBC.

\section{Selection of virus strain}

Two strains of NDV were selected for the study where one is lasota strain from commercial vaccine (Intervet, The Netherlands). Another is field isolate of very virulent NDV (VVNDV), collected from the Department of Microbiology and Veterinary Public Health laboratory, CVASU. The field isolate previously isolated and stored at $-86^{\circ} \mathrm{C}$. The stock virus treated with gentamicin after thawing of virus to remove the bacterial contamination. We treated gentamicin $500 \mu \mathrm{g} / \mathrm{mL}$ of inoculum at room temperature for $1 / 2 \mathrm{~h}$ to inactivate bacteria if present. The sterility of inoculum was checked by adding few drops of inoculum into nutrient agar and blood agar. No growth was observed after $24 \mathrm{~h}$ of incubation keeping at $37^{\circ} \mathrm{C}$.

\section{Propagating of virus}

Both the virus (vaccine and field isolate) were propagated in 9-day-old embryonated chicken eggs which were collected from the hatchery. The eggs were candled and marked inoculation sites. Eggs were placed in an egg rack with the inoculation site uppermost. By using cotton wool and 70\% alcohol to swab the end of the eggs to be inoculated and allowed to evaporate the alcohol. Viral inoculum was treated with gentamicin and kept it 20 min before inoculation. Pierced a hole in the end of the egg at the marked inoculation site by a dental drill. By attaching the needle drawn inoculum into $1 \mathrm{ml}$ syringe. $0.1 \mathrm{ml}$ of inoculum was injected into the egg through the hole in the eggshell by keeping the needle and syringe vertical position. The needle was withdrawn from the egg and the hole in shell was sealed with nail polish. After that the used needles and syringes were discarded. The inoculated eggs were placed into incubator for $48 \mathrm{~h}$. The embryo was checked after $24 \mathrm{~h}$ of inoculation for any death of embryo. After $48 \mathrm{~h}$ of incubation eggs were transferred to chilling temperature for $24 \mathrm{~h}$ [16].

\section{Collection of allantoic fluid}

After $24 \mathrm{~h}$ of chilling, embryonated eggs were placed into a biological safety cabinet. The egg shell was broken on the top by using sterile forceps, opened at the air sac and pulled back the allantoic membrane. The all egg fragments were placed, including parts of the shell into a materials bag. Allantoic fluid was harvested from each egg by using a sterile syringe being careful not to sucked up yolk or blood with the allantoic fluid. All allantoic fluid has been collected (pooled) and aliquot the collected fluid into Eppendorf tubes and freezer at $-86^{\circ} \mathrm{C}$ to use as stock.

\section{Preparation of $1 \%$ RBC}

Collected blood was transferred to a falcon tube suitable for centrifugation and added phosphate buffered saline (PBS) to fill the tube. The sample was centrifuged at $1500 \mathrm{rpm}$ for $10 \mathrm{~min}$ and discarded the supernatant by using a Pasteur pipette. Care was taken not to disturb the pellet of RBCs and centrifugation step was repeated for 3 times. The cells now formed a pellet after being washed 3 times and centrifuged. The 
next step was measured and prepared the $1 \%$ solution of cells for storage by adding $1 \mathrm{ml}$ packed cell with $99 \mathrm{ml}$ PBS [16].

\section{Preparation of 4 HA unit virus}

One HA unit in the HA titration is the minimum amount of virus that will cause complete agglutination of the RBCs. HA test was performed using $1 \%$ chicken RBC with two-fold dilution of the virus to detect the concentration of virus. The last well in the 96-well plates that shows the complete HA with $1 \%$ chicken RBC contains one HA unit. The well that contains 4 HA unit was identified and calculated the dilution factor. 4 HA unit virus suspension was prepared by adding $1 \mathrm{ml}$ virus with required amount of diluent [16].

\section{HA test}

$50 \mu \mathrm{L}$ of PBS was dispensed into each well of the microwell plate up to column $7.50 \mu \mathrm{L}$ of test samples (virus) were placed in the first well of each row of column 1. By using a multichannel pipette, twofold serial dilutions carried out across the plate until column 6 . Then, $50 \mu \mathrm{L}$ of $1 \%$ RBCs of tested species was added in each well including column 7 . The wells in this column 7 are control wells that contain only PBS and RBCs. Gently tapped the sides of the plate to mix and placed a cover on the plate and allow the plate to stand in three different temperatures (e.g., chilling, room temperature, and incubation temperature). Result was taken at every 5 min after the settlement of $\mathrm{RBC}$ in control row. Result was recorded in a data sheet [16].

\section{Data analysis}

Obtained data were entered into spreadsheets of the MS Excel-2007 Program. Data were sorted and cleaned in the Excel program before exporting to STATA-11. t-test was performed to compare HA at different temperatures for different species of RBC by two strains of NDV. One-way ANOVA was carried out to compare the time required for HA within species by two virus strains at three different temperatures. A $p<0.05$ was considered statistically significant.

\section{Result}

\section{HA activity of avian RBC with ND lasota strain}

For ND lasota strain HA was observed in six microwell plates for a single species of RBC at three different temperatures (chilling temperature, incubation temperature, and room temperature) depicted in Table-1. It was observed that in all cases the highest time was required for the HA activity at chilling temperature. The lowest time for HA activity was required at incubation temperature. Among the chilling temperature, the highest time (57.5 min) was recorded in case of chicken and the lowest time (29.06 $\mathrm{min}$ ) was recorded in case of pigeon. At different incubation temperature, the highest time (24.69 $\mathrm{min}$ ) was recorded in case of chicken and the lowest time (17.81 min) was recorded in case of duck. At different room temperature, the highest time (32.19 min) was recorded in case of chicken and the lowest time (21.25 $\mathrm{min}$ ) was recorded in case of duck.

\section{HA activity of avian RBC with VVNDV field isolate}

In case of VVNDV among the avian species at chilling temperature, the highest time (56.26 $\mathrm{min})$ for HA activity was recorded in case of chicken and the lowest time (28.59 $\mathrm{min})$ was recorded in case of quail. Among the incubation temperature, the highest time $(23.19 \mathrm{~min})$ was recorded in case of chicken and the lowest time (17.81 min) was recorded in case of duck. At room temperature, the highest time (31.25 min) was recorded in case of chicken and the lowest time (22.50 min) was recorded in case of duck shown in Table- 2 .

\section{HA activity of mammalian RBC with ND lasota strain}

In case of ND lasota virus among the mammalian species at all three different temperatures, the highest time for HA activity was recorded in case of goat and the lowest time was recorded in case of horse described in Table-3.

\section{HA of mammalian RBC with VVNDV field isolate virus}

In case of VVNDV among the mammalian species at chilling temperature, the highest time (175.94 $\mathrm{min}$ ) for HA activity was recorded in case of goat and the lowest time (64.06 $\mathrm{min})$ was recorded in case of horse. Among the incubation temperature, the highest time (125.63 $\mathrm{min}$ ) was recorded in case of goat and the lowest time (52.66 $\mathrm{min}$ ) was recorded in case of horse. Among the room temperature, the highest time (168.13 min) was recorded in case of goat and the lowest time $(58.13 \mathrm{~min})$ was recorded in case of dog shown in Table-4.

\section{HA activity of human RBC with ND lasota virus}

In case of ND lasota virus among the human blood group at chilling temperature, the highest time (112.50 $\mathrm{min}$ ) for HA activity was recorded in case of $\mathrm{AB}+$ and the lowest time (95.93 $\mathrm{min}$ ) was recorded in case of $\mathrm{A}+$. Among the incubation temperature, the highest time (71.88 min) was recorded in case of Band the lowest time (55.93 $\mathrm{min}$ ) was recorded in case of $\mathrm{A}+$ and $\mathrm{A}-$. Among the room temperature, the highest time $(85.39 \mathrm{~min})$ was recorded in case of $\mathrm{B}-$ and the lowest time (64.69 $\mathrm{min}$ ) was recorded in case of $\mathrm{A}+$ blood group reflected in Table-5.

\section{HA activity of human RBC with VVNDV}

In case of VVNDV among the avian human blood group at chilling temperature, the highest time (109.69 $\mathrm{min}$ ) for HA activity was recorded in case of $\mathrm{AB}+$ and the lowest time $(86.57 \mathrm{~min})$ was recorded in case of $\mathrm{A}-$. Among the incubation temperature, the highest time (69.00 min) was recorded in case of B- and the lowest time (55.63 $\mathrm{min})$ was recorded in case of $\mathrm{A}-$. Among the room temperature, the highest time (75.31 min) was recorded in case of $\mathrm{AB}+$ and the lowest time (60.31 min) was recorded in case of $\mathrm{B}+$ blood group described in Table-6. Among the eight individual blood groups of human RBCs require almost similar time at 
Available at www.onehealthjournal.org/Vol.3/5.pdf

Table-1: Time required for HA of avian RBC with NDV (lasota strain) at different temperatures (mean \pm SD).

\begin{tabular}{|c|c|c|c|c|}
\hline Species & $\begin{array}{c}\text { Chilling } \\
\text { temperature } / 4^{\circ} \mathrm{C}(\mathrm{min})\end{array}$ & $\begin{array}{c}\text { Incubation } \\
\text { temperature } / 37^{\circ} \mathrm{C}(\mathrm{min})\end{array}$ & $\begin{array}{l}\text { Room } \\
\text { temperature } / 24^{\circ} \mathrm{C}(\mathrm{min})\end{array}$ & p value \\
\hline Chicken & $57.5 \pm 6.06$ & $24.69 \pm 4.04$ & $32.19 \pm 3.15$ & 0.001 \\
\hline Duck & $29.69 \pm 3.40$ & $17.81 \pm 3.63$ & $21.25 \pm 6.0$ & \\
\hline Geese & $34.06 \pm 3.75$ & $21.56 \pm 3.01$ & $29.69 \pm 4.23$ & \\
\hline Pigeon & $29.06 \pm 3.75$ & $20.31 \pm 3.40$ & $24.38 \pm 3.60$ & \\
\hline Quail & $29.68 \pm 3.86$ & $22.81 \pm 2.56$ & $25.63 \pm 3.10$ & \\
\hline
\end{tabular}

$\mathrm{HA}=$ Hemaglutination, $\mathrm{RBC}=$ Red blood cell, NDV=Newcastle disease virus, SD: Standard deviation

Table-2: Time required for HA of avian RBC with VVNDV (field isolate) at different temperatures (mean \pm SD).

\begin{tabular}{lcccc}
\hline Species & $\begin{array}{c}\text { Chilling } \\
\text { temperature } / \mathbf{4}^{\circ} \mathbf{C}(\mathbf{m i n})\end{array}$ & $\begin{array}{c}\text { Incubation } \\
\text { temperature } / \mathbf{3 7}^{\circ} \mathbf{C}(\mathbf{m i n})\end{array}$ & $\begin{array}{c}\text { Room } \\
\text { temperature } / \mathbf{2 4} \mathbf{}^{\circ} \mathbf{C}(\mathbf{m i n})\end{array}$ & $\mathbf{p}$ value \\
\hline Chicken & $56.25 \pm 5.96$ & $23.13 \pm 3.10$ & $31.25 \pm 3.42$ \\
Duck & $29.69 \pm 3.35$ & $17.81 \pm 3.64$ & $22.50 \pm 4.09$ \\
Geese & $33.13 \pm 3.54$ & $20.94 \pm 3.23$ & $28.44 \pm 3.52$ \\
Pigeon & $29.84 \pm 3.91$ & $19.38 \pm 3.59$ & $22.81 \pm 4.07$ \\
Quail & $28.59 \pm 3.64$ & $20.63 \pm 3.59$ & $24.06 \pm 3.28$ \\
\hline
\end{tabular}

$\mathrm{HA}=$ Hemaglutination, $\mathrm{RBC}=$ Red blood cell, VVNDV=Very virulent Newcastle disease virus, SD: Standard deviation

Table-3: Time required for HA of mammalian RBC with NDV (lasota strain) within different temperatures (mean \pm SD).

\begin{tabular}{lcccc}
\hline Species & $\begin{array}{c}\text { Chilling } \\
\text { temperature } / \mathbf{4}^{\circ} \mathbf{C}(\mathbf{m i n})\end{array}$ & $\begin{array}{c}\text { Incubation } \\
\text { temperature } / \mathbf{3 7}^{\circ} \mathbf{C}(\mathbf{m i n})\end{array}$ & $\begin{array}{c}\text { Room } \\
\text { temperature/24} \mathbf{~}^{\circ} \mathbf{C}(\mathbf{m i n})\end{array}$ & p value \\
\hline Goat & $184.68 \pm 6.18$ & $125.31 \pm 6.70$ & $173.75 \pm 6.95$ \\
Sheep & $78.13 \pm 4.43$ & $58.75 \pm 3.87$ & $70.00 \pm 4.83$ \\
Horse & $67.50 \pm 4.83$ & $51.25 \pm 4.28$ & $56.25 \pm 5.32$ \\
Cattle & $72.50 \pm 4.47$ & $54.38 \pm 4.43$ & $62.81 \pm 4.64$ \\
Buffalo & $71.57 \pm 4.37$ & $55.00 \pm 4.47$ & $64.06 \pm 3.75$ \\
Dog & $69.38 \pm 4.78$ & $54.38 \pm 3.59$ & $64.06 \pm 2.72$ \\
\hline
\end{tabular}

$\mathrm{HA}=$ Hemaglutination, $\mathrm{RBC}=$ Red blood cell, NDV=Newcastle disease virus, SD: Standard deviation

Table-4: Time required for HA of mammalian RBC with VVNDV (field strain) within different temperatures (mean \pm SD).

\begin{tabular}{lcccc}
\hline Species & $\begin{array}{c}\text { Chilling } \\
\text { temperature } / \mathbf{4}^{\circ} \mathbf{C}(\mathbf{m i n})\end{array}$ & $\begin{array}{c}\text { Incubation } \\
\text { temperature } / \mathbf{3 7}^{\circ} \mathbf{C}(\mathbf{m i n})\end{array}$ & $\begin{array}{c}\text { Room } \\
\text { temperature/24} \mathbf{~}^{\circ} \mathbf{C}(\mathbf{m i n})\end{array}$ & $\mathbf{p}$ value \\
\hline Goat & $175.94 \pm 6.12$ & $125.63 \pm 6.08$ & $168.13 \pm 7.27$ \\
Sheep & $76.25 \pm 4.29$ & $59.22 \pm 3.83$ & $67.81 \pm 4.47$ \\
Horse & $64.06 \pm 4.56$ & $52.66 \pm 4.40$ & $59.38 \pm 4.03$ \\
Cattle & $73.75 \pm 3.42$ & $53.44 \pm 4.99$ & $64.38 \pm 3.10$ \\
Buffalo & $70.94 \pm 5.84$ & $54.69 \pm 4.57$ & $60.94 \pm 4.91$ \\
Dog & $70.00 \pm 4.48$ & $52.67 \pm 5.39$ & $58.13 \pm 5.74$ \\
\hline
\end{tabular}

$\mathrm{HA}=$ Hemaglutination, $\mathrm{RBC}=$ Red blood cell, VVNDV=Very virulent Newcastle disease virus, SD: Standard deviation

Table-5: Time required for HA of human RBC with NDV (lasota strain) within different temperatures (mean \pm SD).

\begin{tabular}{|c|c|c|c|c|}
\hline Blood group & $\begin{array}{c}\text { Chilling } \\
\text { temperature } / 4^{\circ} \mathrm{C}(\mathrm{min})\end{array}$ & $\begin{array}{l}\text { Incubation } \\
\text { temperature } / 37^{\circ} \mathrm{C}(\mathrm{min})\end{array}$ & $\begin{array}{l}\text { Room } \\
\text { temperature } / 24^{\circ} \mathrm{C}(\mathrm{min})\end{array}$ & p value \\
\hline$A+$ & $95.93 \pm 5.83$ & $55.93 \pm 4.91$ & $64.69 \pm 4.64$ & 0.001 \\
\hline$A-$ & $97.18 \pm 6.31$ & $55.93 \pm 4.91$ & $65.00 \pm 4.08$ & \\
\hline$B+$ & $99.38 \pm 9.28$ & $61.25 \pm 5.00$ & $69.38 \pm 9.70$ & \\
\hline$B-$ & $96.87 \pm 5.12$ & $71.88 \pm 4.78$ & $85.39 \pm 5.38$ & \\
\hline $\mathrm{AB}+$ & $112.50 \pm 7.30$ & $63.75 \pm 5.91$ & $75.00 \pm 7.30$ & \\
\hline$A B-$ & $101.56 \pm 5.39$ & $62.35 \pm 4.71$ & $70.28 \pm 5.14$ & \\
\hline
\end{tabular}

$\mathrm{HA}=$ Hemaglutination, $\mathrm{RBC}=$ Red blood cell, NDV=Newcastle disease virus, SD: Standard deviation

a specific temperature but $\mathrm{O}+$ and $\mathrm{O}-$ do not show any $\mathrm{HA}$ activity against any one of the virus strains.

\section{Comparison of HA activity of avian RBC with two strains of NDV}

At chilling temperature, the highest time (57.5 $\mathrm{min}$ ) for HA activity was recorded in case of chicken and the lowest time (27.55 min) was recorded in case of quail. There was no significant variation of time requirement for HA activity within different avian species. In case of quail, $\mathrm{p}=0.09$ indicating a very close to significant variation of time requirement by VVNDV and ND lasota vaccine strain. At incubation temperature, the highest time $(24.69 \mathrm{~min})$ for 
HA activity was recorded in case of chicken and the lowest time (17.81 min) was recorded in case of duck. In case of quail, $p=0.05$ indicates a significant variation of time requirement by VVNDV and ND lasota vaccine strain. At room temperature, the highest time (32.19 $\mathrm{min}$ ) for HA activity was recorded in case of chicken and the lowest time (21.25 min) was recorded in case of duck. There was no significant variation of time requirement for HA activity within different avian species at room temperature depicted in Table-7.

\section{Comparison of HA activity of mammalian RBC with two strains of NDV}

At chilling temperature, the highest time (184.69 $\mathrm{min}$ ) for HA activity was recorded in case of goat and the lowest time (64.06 $\mathrm{min}$ ) was recorded in case of horse. In case of goat, the $p=0.04(p<0.05)$ and in case horse $\mathrm{p}=0.04(\mathrm{p}<0.05)$ indicating a very close to significant variation of time requirement by VVNDV and ND lasota vaccine strain. At incubation temperature, the highest time (125.98 min) for HA activity was recorded in case of goat and the lowest time (50.94 min) was recorded in case of dog. In case of horse the $\mathrm{p}=0.06$ indicating a very close significant variation of time requirement by VVNDV and ND lasota vaccine strain. At room temperature the highest time $(173.75 \mathrm{~min})$ for HA activity was recorded in Table- 8 . In case of goat and the lowest time $(56.25 \mathrm{~min})$ was recorded in case of horse. In case of goat the $p=0.033(p<0.05)$, in case buffalo $p=0.05$ and in $\operatorname{dog} \mathrm{p}=0.0012(\mathrm{p}<0.05)$ indicating a very close to significant variation of time requirement by VVNDV and ND lasota vaccine strain at room temperature.

\section{Comparison of HA activity of human RBC with two strains of NDV}

At chilling temperature, the highest time (112.5 $\mathrm{min}$ ) for HA activity was recorded in case of $\mathrm{AB}+$ and the lowest time $(86.56 \mathrm{~min})$ was recorded in case of $\mathrm{A}-$. In case of $\mathrm{A}+, \mathrm{A}-$ and $\mathrm{B}-$ blood group $\mathrm{p}<0.05$ indicating a very close to significant variation of time requirement by VVNDV and ND lasota vaccine strain. At incubation temperature, the highest time (65.31 minutes) for HA activity was recorded in case of $\mathrm{AB}+$ and the lowest time (54.06 minutes) was recorded in case of $\mathrm{A}+$. In case of $\mathrm{B}+$ and $\mathrm{B}-$ and $\mathrm{B}-$ blood group $\mathrm{p}<0.05$ indicating a very close to significant variation of time requirement by VVNDV and ND lasota vaccine strain shown in Table-9. At room temperature, the highest time $(86.88 \mathrm{~min})$ for $\mathrm{HA}$ activity was recorded in case of $\mathrm{B}+$ and the lowest time $(60.31 \mathrm{~min})$ was recorded in case of $A+$. In case of

Table-6: Time required for HA of human RBC with VVNDV (field isolate) within different temperatures (mean \pm SD).

\begin{tabular}{|c|c|c|c|c|}
\hline Blood group & $\begin{array}{c}\text { Chilling } \\
\text { temperature } / 4^{\circ} \mathrm{C}(\mathrm{min})\end{array}$ & $\begin{array}{l}\text { Incubation } \\
\text { temperature } / 37^{\circ} \mathrm{C}(\mathrm{min})\end{array}$ & $\begin{array}{l}\text { Room } \\
\text { temperature } / 24^{\circ} \mathrm{C}(\mathrm{min})\end{array}$ & p value \\
\hline$A+$ & $90.62 \pm 4.42$ & $59.06 \pm 3.75$ & $69.31 \pm 4.27$ & 0.001 \\
\hline$A-$ & $86.57 \pm 5.98$ & $55.63 \pm 5.12$ & $62.81 \pm 7.00$ & \\
\hline $\mathrm{B}+$ & $97.50 \pm 8.16$ & $58.13 \pm 5.74$ & $60.31 \pm 5.31$ & \\
\hline$B-$ & $89.68 \pm 4.98$ & $69.00 \pm 4.55$ & $74.69 \pm 3.40$ & \\
\hline$A B+$ & $109.69 \pm 7.18$ & $65.31 \pm 3.90$ & $75.31 \pm 5.62$ & \\
\hline$A B-$ & $105.93 \pm 6.11$ & $63.13 \pm 4.43$ & $65.63 \pm 3.10$ & \\
\hline
\end{tabular}

$\mathrm{HA}=$ Hemaglutination, $\mathrm{RBC}=$ Red blood cell, VVNDV=Very virulent Newcastle disease virus, SD: Standard deviation

Table-7: Comparing time requirement (min) of HA activity of avian RBC with two strains of NDV at different temperatures.

\begin{tabular}{|c|c|c|c|c|c|c|c|c|c|}
\hline \multirow[t]{2}{*}{ Species } & \multicolumn{3}{|c|}{ Chilling temperature $\left(4^{\circ} \mathrm{C}\right)$} & \multicolumn{3}{|c|}{ Incubation temperature $\left(37^{\circ} \mathrm{C}\right)$} & \multicolumn{3}{|c|}{ Room temperature $\left(24^{\circ} \mathrm{C}\right)$} \\
\hline & ND lasota & Field isolate & p value & ND lasota & Field isolate & p value & ND lasota & Field isolate & p value \\
\hline & & & & & & & & & 0.4 \\
\hline & 29.6 & & & & & & & & \\
\hline Geese & $34.06 \pm 0.49$ & & & & & & & & 0.37 \\
\hline Pigeon & $29.06 \pm 0.94$ & $30.63 \pm 1.01$ & 0.26 & $20.31 \pm 0.85$ & $19.84 \pm 0.61$ & & $24.38 \pm 0.90$ & $22.81 \pm 1.02$ & 0.26 \\
\hline Quail & $29.69 \pm 0.96$ & $27.50 \pm 0.79$ & 0.09 & $22.81 \pm 0.64$ & $20.62 \pm 0.89$ & 0.05 & $25.63 \pm 0.77$ & $24.06 \pm 0.81$ & 0.17 \\
\hline
\end{tabular}

$\mathrm{HA}=$ Hemaglutination, $\mathrm{RBC}=$ Red blood cell, NDV=Newcastle disease virus, SD: Standard deviation

Table-8: Comparing HA of mammalian RBC with two strains of NDV at different temperatures.

\begin{tabular}{|c|c|c|c|c|c|c|c|c|c|}
\hline \multirow[t]{2}{*}{ Species } & \multicolumn{3}{|c|}{ Chilling temperature $/ 4^{\circ} \mathrm{C}$} & \multicolumn{3}{|c|}{ Incubation temperature $/ 37^{\circ} \mathrm{C}$} & \multicolumn{3}{|c|}{ Room temperature $/ 24^{\circ} \mathrm{C}$} \\
\hline & ND lasota & Field isolate & p value & ND lasota & Field isolate & p value & ND lasota & Field isolate & p value \\
\hline Goat & $184.69 \pm 1.54$ & $175.93 \pm 1.52$ & 0.004 & $125.31 \pm 1.67$ & $125.98 \pm 1.39$ & 0.778 & $173.75 \pm 1.4$ & $168.13 \pm 1.82$ & 0.033 \\
\hline Sheep & $78.13 \pm 1.11$ & $76.25 \pm 1.07$ & 0.233 & $58.75 \pm 0.97$ & $59.69 \pm 0.96$ & 0.59 & $70 \pm 1.21$ & $67.81 \pm 1.37$ & 0.239 \\
\hline Horse & $67.5 \pm 1.21$ & $64.06 \pm 1.11$ & 0.047 & $51.25 \pm 1.07$ & $54.06 \pm 1.04$ & 0.06 & $56.25 \pm 1.33$ & $59.38 \pm 1.00$ & 0.07 \\
\hline Cattle & $72.5 \pm 1.12$ & $73.75 \pm 0.85$ & 0.381 & $54.38 \pm 1.11$ & $.5 \pm 1.37$ & 0.29 & $62.81 \pm 1.12$ & $64.38 \pm 0.77$ & 0.259 \\
\hline Buffalo & $71.56 \pm 1.09$ & $70.94 \pm 1.06$ & 0.734 & $55.01 \pm 1.12$ & $54.38 \pm 1.2$ & 0.70 & $64.06 \pm 0.94$ & $60.94 \pm 1.22$ & 0.05 \\
\hline Dog & $69.38 \pm 1.20$ & $70.00 \pm 1.12$ & 0.705 & $54.38 \pm 0.90$ & $50.94 \pm 1.6$ & 0.07 & $64.06 \pm 0.67$ & $58.13 \pm 1.43$ & 0.0012 \\
\hline
\end{tabular}

$\mathrm{HA}=$ Hemaglutination, $\mathrm{RBC}=$ Red blood cell, NDV=Newcastle disease virus, ND=Newcastle disease 
Table-9: Comparing HA of human RBC with two strains of NDV at different temperatures.

\begin{tabular}{|c|c|c|c|c|c|c|c|c|c|}
\hline \multirow[t]{2}{*}{ Blood group } & \multicolumn{3}{|c|}{ Chilling temperature $\left(4^{\circ} \mathrm{C}\right) / \mathrm{min}$} & \multicolumn{3}{|c|}{$\begin{array}{c}\text { Incubation } \\
\text { temperature }\left(37^{\circ} \mathrm{C}\right) / \mathrm{min}\end{array}$} & \multicolumn{3}{|c|}{$\begin{array}{c}\text { Room } \\
\text { temperature }\left(24^{\circ} \mathrm{C}\right) / \mathrm{min}\end{array}$} \\
\hline & ND lasota & Field isolate & p value & ND lasota & $\begin{array}{c}\text { Field } \\
\text { isolate }\end{array}$ & p value & ND lasota & $\begin{array}{c}\text { Field } \\
\text { isolate }\end{array}$ & p value \\
\hline & & & & & $4.06 \pm 0.93$ & & & $60.31 \pm 1.06$ & 0.00 \\
\hline A- & $97.19 \pm 1.57$ & $86.56 \pm 1.49$ & 0.00 & $55.93 \pm 1.22$ & $55.63 \pm 1.28$ & & $65.0 \pm 1.02$ & 1.77 & 0.29 \\
\hline $\mathrm{B}+$ & $99.38 \pm 2.32$ & $97.5 \pm 1.53$ & 0.54 & $61.87 \pm 1.0$ & $58.12 \pm 1.43$ & 0.04 & $69.68 \pm 1.24$ & $60.31 \pm 1.32$ & 0.00 \\
\hline$B-$ & $96.88 \pm 1.28$ & $89.69 \pm 1.24$ & 0.00 & $72.5 \pm 0.91$ & $69.06 \pm 1.13$ & 0.02 & $86.88 \pm 1.28$ & $74.68 \pm 0.85$ & 0.00 \\
\hline$A B+$ & $112.5 \pm 1.83$ & $109.69 \pm 1.8$ & 0.28 & $63.13 \pm 1.43$ & $65.31 \pm 0.96$ & 0.22 & $74.06 \pm 1.52$ & $75.32 \pm 1.40$ & 0.55 \\
\hline$A B-$ & $105.93 \pm 1.52$ & $105.93 \pm 1.52$ & 1.00 & $62.5 \pm 1.2$ & $63.12 \pm 1.10$ & 0.70 & $70.12 \pm 1.29$ & $65.63 \pm 0.77$ & 0.00 \\
\hline
\end{tabular}

$\mathrm{HA}=$ Hemaglutination, $\mathrm{RBC}=$ Red blood cell, NDV $=$ Newcastle disease virus, ND=Newcastle disease

$\mathrm{A}+, \mathrm{B}+, \mathrm{B}-$ and $\mathrm{AB}-$ blood group $\mathrm{p}<0.05$ indicating a very close to significant variation of time requirement by VVNDV and ND lasota vaccine strain.

\section{Discussion}

ND is still scrutinized as an economically significant disease which is highly contagious nature in infection for many avian species throughout the globe $[17,18]$. The study was conducted to characterize the HA activity of NDV by using different species of avian and mammalian RBC at three different temperatures. The HA activity of NDV is concerned with virus identification and measurement of antibody [19]. Their thermostability, the agglutination of mammalian erythrocytes, the rate of elution from chicken erythrocytes, the responsiveness to monoclonal antibodies, and the inhibition by lectin-binding were all investigated to classify NDV strains $[17,20]$.

Among the species, it has been observed that avian $\mathrm{RBC}$ require less time for agglutination than mammalian RBC. It may due to the presence of nucleus in avian RBC which makes it easy settle down within short time than mammalian RBC. On the other hand, the test can be used to characterize NDV in rapid and cheapest way [14].

The research reveals that incubation temperature $\left(37^{\circ} \mathrm{C}\right)$ require lowest time to generate HA activity irrespective of species, chilling temperature need highest time for agglutination of RBC and room temperature require time in between incubation and chilling temperature. Similar observation was also recorded by Hussain et al. [21] and Awad et al. [22] in avian influenza virus and by Hawkes [23] in hepatitis B. The mechanism underlying this observation of indifferences in agglutination activity of virus strain possibly associated with the variable level of enzymatic activity that is optimum at incubation temperature $\left(37^{\circ} \mathrm{C}\right)$ and decreases with decreasing temperature [24].

Both ND lasota and virulent field isolate NDV agglutinate all avian and mammalian $\mathrm{RBC}$ with variable time requirement. It has been found that among avian $\mathrm{RBC}$, highest agglutination time was recorded in chicken $(57.5 \mathrm{~min})$ at chilling temperature and lowest time was recorded in duck $(17.81 \mathrm{~min})$ at incubation temperature. In case of mammalian RBC highest time was recorded in goat $(184.68 \mathrm{~min})$ at chilling temperature and lowest time was recorded in horse (51.25 min). Similar observation was described by Hussain et al. [21], Awad et al. [22], Couceiro et al. [25], Ibu et al. [26], Adebayo [27], but there was strain variability in agglutination. Adair et al. [28] and Lu et al. [29] found that some avian and mammalian viruses agglutinate the erythrocytes of certain animals. In the study, Ibu et al. [26] found that five virus strains (Bn2, Bn8, Herts, Kudu, NCD) failed to agglutinate bovine and equine RBC. This HA property reflects the fact that such erythrocytes possess receptors for certain surface components of the virus particle that function as cell attachment protein. The cell receptors for paramyxoviruses (NDV) are $\mathrm{HN}$ is a multifunctional molecule. $\mathrm{HN}$ is responsible for the attachment of virus to receptors containing sialic acid expressed by different complex gangliosidic structures as GD 1a, GT 1b, and GQ 1b [30,31] which could be abundant on cell surfaces of erythrocytes originated from specific animal origins.

In case human $\mathrm{RBC}$ among the eight different blood groups $\left(\mathrm{A}+, \mathrm{A}^{-}, \mathrm{B}+, \mathrm{B}^{-}, \mathrm{AB}+\right.$, and $\left.\mathrm{AB}^{-}\right)$show complete agglutination of RBC by ND lasota and VVNDV except $\mathrm{O}$ blood group which does not show any agglutination by both virus strains. Couceiro et al. [25] found similar result but he found variation in HA activity in case of human "O" blood group that may be attributed to lack of any surface antigen in human "O" blood group which showed the occurrence of variability in the amount and specificity of erythrocyte receptors in paramyxovirus [25,32]. Comparing the time requirements to show HA activity among different species of RBC with two NDV strains at different temperatures have also been studied. At chilling temperature, there was no significant variation of time requirement for HA activity in between two strains of NDV. At incubation temperature, there was significant difference $(p=0.05)$ observed in quail this may be due to strain variability of NDV that do not recognize the sialic acid receptor exhibited by same RBC [25]. At room temperature, there was no significant variation found in two strains of NDV.

The variability in the pattern of agglutination of certain mammalian erythrocytes by the field virus and lasota strains demonstrated herewith. The pattern of variability as observed could be of theoretical and 
practical significance. Among mammalian species at chilling temperature in case of goat the $p=0.04$ $(p<0.05)$ and in case horse $p=0.047(p<0.05)$ indicating significant variation of time requirement by VVNDV and ND lasota vaccine strains. At room temperature, significant variation was observed in goat $(\mathrm{p}=0.033)$, buffalo $(\mathrm{p}=0.05)$, and $\operatorname{dog}(\mathrm{p}=0.0012)$ that might be due to some intra-strain differences are still apparent in terms of their hemagglutinability patterns [26]. The selective ability of mammalian RBCs as a tool for differentiation between natural and vaccinal strain in a serological test has been reported by Adebayo [27].

In human $\mathrm{RBC}$, at chilling temperature in blood group $\mathrm{A}+[\mathrm{p}=0.007), \mathrm{A}^{-}(\mathrm{p}=0.00)$, and $\mathrm{B}-(\mathrm{p}=0.00)$, $\mathrm{p}<0.05$ indicating a significant variation of time requirement by VVNDV and ND lasota vaccine strains. At incubation temperature in blood group $\mathrm{B}+$ $(\mathrm{p}=0.04)$ and $\mathrm{B}-(\mathrm{p}=0.02)$ and at room temperature in blood group $\left(\mathrm{A}+, \mathrm{B}+, \mathrm{B}^{-}\right.$and $\left.\mathrm{AB}^{-}\right), \mathrm{p}<0.05$ indicating a significant variation of time requirement by VVNDV and ND lasota vaccine strains. The variation in agglutinability of most mammalian erythrocytes by the velogenic strains appears to agree with the findings of Haruna et al. [33]. These workers observed a direct linkage between the agglutinability of mammalian RBCs and virulence of NDVs. A similar observation evidenced earlier [34]. The latter authors concluded that the agglutination of erythrocytes of different animal species could serve as a quick means of identifying and separating different viruses as well as different strains of one and the same virus.

The fact that mammals are not natural hosts of NDV in addition to their availability and easy management make them good candidates or substitutes for specific pathogen-free chickens in the supply of indicator systems for Hemagglutination Inhibition titrations. However, Adebayo [27] observed that some erythrocyte indicator systems differed in their sensitivity to the detection of ND antibody.

\section{Conclusion}

ND remains a constant threat to the poultry industry, limiting disease for poultry producers worldwide. The variety of clinical presentations and the emergence and spread of new genetic variants make recognition and diagnosis challenging. Presently, we confirm that the NDV of vaccine and field strain were agglutinate the avian, mammalian and human $\mathrm{RBC}$ at three different temperatures with variable time except human "O" blood group which is not agglutinated by any one of the virus strains. In every species of RBC, incubation temperature requires less time for HA than room temperature while chilling temperature requires higher time for HA than other two temperatures. Avian species required less time for HA than mammalian species. A significant variation of time requirements for HA activity also observed in some species and human blood group. It is recommended that various factors such as source of erythrocytes, type of diluent, incubation time, and $\mathrm{pH}$ variation can be evaluated with their potential effects on HA activity.

\section{Authors' Contributions}

HU: Conception and design, sample collection, laboratory works, data analysis and interpretation, review of the manuscript. KI: Assist in laboratory testing, analysis and interpretation of the data, writing and drafting the manuscript, critical review of the manuscript. MB: Assist in drafting, designing, cross checking and critical review of the manuscript, reference list crosschecking. SI: Reference list crosschecking and review of the manuscript. AA: Overall supervision, conception and design, instruction and review of analysis and critical review of the manuscript. All authors read and approved the final manuscript.

\section{Acknowledgments}

The research work was funded by Centre for Advanced Studies and Research, Chittagong Veterinary and Animal Sciences University (CVASU). Authors are also grateful to the Department of Microbiology and Veterinary Public Health, Faculty of Veterinary Medicine, CVASU and Poultry Research and Training Center, Bangladesh, for providing laboratory support to the present research study.

\section{Competing Interests}

The authors declare that they have no competing interests.

\section{References}

1. Abdu P, Oladele SB. Awareness of farmers on Newcastle Disease, its vaccination and antibody titer in commercial chickens in Jos South, Nigeria. J World Poult Res 2016;6:84-91.

2. Islam KM, Uddin MF, Alam MM. Challenges and prospects of poultry industry in Bangladesh. Eur J Bus Manage 2014;6:116-27.

3. Das SC, Chowdhury SD, Khatun MA, Nishibori M, Isobe N, Yoshimura Y. Poultry production profile and expected future projection in Bangladesh. Worlds Poult Sci J 2008;64:99-118.

4. Alexander DJ. Newcastle disease and other avian paramyxoviruses. Rev sci tech 2000;19(2):443-62.

5. Ahad A, Rabbani M, Yaqub T, Mahmood A, Kuthu ZH, Shabbir MZ, et al. Detection of antibody to newcastle disease virus in human sera in Pakistan. J Anim Plant Sci 2013;23:990-4

6. Uddin MA, Islam K, Sultana S, Imtiaz MA, Saifuddin AK, Barua M. Seroprevalence of antibodies against Newcastle disease in layer chicken at Cox's Bazar, Bangladesh. Res J Vet Pract 2014;2:36-9.

7. Cattoli G, Susta L, Terregino C, Brown C. Newcastle disease: A review of field recognition and current methods of laboratory detection. J Vet Diagn Invest 2011;23:637-56.

8. Orajaka LJ, Adene DF, Anene BM, Onuoha EA. Seroprevalence of Newcastle disease in local chickens from southeast derived savannah zone of Nigeria - Prevalencia serologica de la enfermedad de Newcastle en pollos locales de la zona derivada de la sabana sudeste en Nigeria - Seroprevalence de la maladie de Newcastle chez des poulets d'élevage fermier dans la zone de savanes au sud-est du Nigeria. Rev Élev Méd Vét Pays Trop 1999;52:171-9. 
9. de Leeuw OS, Koch G, Hartog L, Ravenshorst N, Peeters BP. Virulence of Newcastle disease virus is determined by the cleavage site of the fusion protein and by both the stem region and globular head of the haemagglutinin-neuraminidase protein. J Gen Virol 2005;86:1759-69.

10. Ogawa R, Yanagida N, Saeki S, Saito S, Ohkawa S, Gotoh $\mathrm{H}$, et al. Recombinant fowlpox viruses inducing protective immunity against Newcastle disease and fowl pox viruses. Vaccine 1990;8:486-90.

11. Karaca K, Sharma JM, Winslow BJ, Junker DE, Reddy S, Cochran $\mathrm{M}$, et al. Recombinant fowlpox viruses coexpressing chicken Type I IFN and Newcastle disease virus $\mathrm{HN}$ and $\mathrm{F}$ genes: Influence of IFN on protective efficacy and humoral responses of chickens following in ovo or post-hatch administration of recombinant viruses. Vaccine 1998;16:1496-503.

12. Sun HL, Wang YF, Tong GZ, Zhang PJ, Miao DY, Zhi HD, et al. Protection of chickens from Newcastle disease and infectious laryngotracheitis with a recombinant fowlpox virus co-expressing the $\mathrm{F}$, $\mathrm{HN}$ genes of Newcastle disease virus and $\mathrm{gB}$ gene of infectious laryngotracheitis virus. Avian Dis 2008;52:111-7.

13. Hines NL, Miller CL. Avian paramyxovirus serotype-1: A review of disease distribution, clinical symptoms, and laboratory diagnostics. Vet Med Int 2012;2012:17.

14. Ezeibe MC, Okoye JA, Ezeala IE, Mbuko IJ, Ngene AA. Comparison of use of agglutination of mammalian erythrocytes plus heat stability test and use of agglutination of mammalian erythrocytes plus erythrocyte elution time to characterize isolates of Newcastle disease virus. Br Micro Res J 2014;4:730-6.

15. Ezeibe MC, Nwokike EC, Eze JI, Eze IC. Detection and characterization of Newcastle disease virus from feaces of healthy frre-roaming chickens in Nsukka, Nigeria. Trop Vet 2006;24:76-80.

16. OIE. Newcastle Disease (Infection with Newcastle Disease Virus); 2012. Available from: http://www.oie.int/ contact;1.04.2014.

17. Bilal ES, Elnasri IM, Alhassan AM, Khalifa KA, Elhag JI, Ahmed SO. Biological pathotyping of Newcastle disease viruses in Sudan 2008-2013. J Vet Med 2014;2014:1-4.

18. Islam S, Islam A, Moni SP, Bari MS, Islam K, Chakma S, et al. A cross sectional study of Infectious Bursal disease and Newcastle disease in poultry in Narsingdi district of Bangladesh. J Adv Vet Anim Res 2016;3:406-2.

19. Alexander D. Newcastle disease and other avian paramyxoviridae infection. Diseases of Poultry. $10^{\text {th }}$ ed. Ames, IA: Iowa State University Press; 1997;541-69.

20. Murakawa Y, Sakaguchi M, Soejima K, Eriguchi S, Takase K, Sueyoshi M, et al. Haemagglutinating activity of the lentogenic Newcastle disease virus strain MET95. Avi
Pathol 2003;32:39-45.

21. Hussain M, Mehmood M, Ahmad A, Shabbir M, Yaqub T. Factors affecting hemagglutination activity of avian influenza virus subtype H5. J Vet Anim Sci 2008;1:31-6.

22. Awad AM, Okela M, Mohamed BA. Factors affecting hemagglutination activity of avian influenza virus subtype H5N1. Alexandria Vet Sci 2012;35:123-30.

23. Hawkes RA. Effect of temperature of the sensitization process on the passive hemagglutination test for hepatitis B antibody. Appl Micro 1973;26:448-9.

24. Ahmed SS, Ersbøll AK, Biswas PK, Christensen JP. The space-time clustering of highly pathogenic avian influenza (HPAI) H5N1 outbreaks in Bangladesh. Epidemiol Infect 2010;138:843-52.

25. Couceiro ES, Couceiro JN, Cabral MC. Hemagglutinating and fusogenic activities of Newcastle disease virus: Studies on receptor binding specificity and $\mathrm{pH}$-induced conformational changes. Mem Inst Oswaldo Cruz 1995;90:515-20.

26. Ibu JO, Okoye JO, Antiabong JF, Yabi GA, Oladele BS. Haemagglutinability of mammalian erythrocytes by newcastle disease virus strains isolated from Central Nigeria. Arch Vet Sci 2009; 14:57-62.

27. Adebayo IA. Application of heterologous erythrocyte indicator systems in the differentiation of vaccinal and natural Newcastle disease induced antibodies. Int J Poult Sci 2004;3:411-4.

28. Adair BM, McFerran JB, Connor TJ, McNulty MS, McKillop ER. Biological and physical properties of a virus (strain 127) associated with the egg drop syndrome 1976. Avi Pathol 1979;8:249-64.

29. Lu YS, Lin DF, Tasi HJ, Lee YL, Chui SY, Lee C, et al. Outbreaks of egg drop syndromen1976 in Taiwan and isolation of the etiological agent. J Chin Soc Vet Sci 1985;11:157-65.

30. Haywood AM. Virus receptors: Binding, adhesion strengthening, and changes in viral structure. J Virol 1994;68:1.

31. Markwell MA, Moss J, Hom BE, Fishman PH, Svennerholm L. Expression of gangliosides as receptors at the cell surface controls infection of NCTC 2071 cells by Sendai virus. Virology 1986;155:356-64

32. Takimoto T, Taylor GL, Connaris HC, Crennell SJ, Portner A. Role of the hemagglutinin-neuraminidase protein in the mechanism of paramyxovirus-cell membrane fusion. J Virol 2002;76:13028-33.

33. Haruna ES, Shamaki D, Echeonwu GO, Majiyagbe KA, Shuaibu Y, Du DR. A natural outbreak of Newcastle disease in guinea-fowl (Numida meleagris Galeata) in Nigeria. Rev Sci Tech 1993;12:887-93.

34. Tolba MK, Eskarous JK. Agglutination of vertebrate erythrocytes by strains of Newcastle disease and fowl-plague viruses. Arch Mikrobiol 1960;35:197-206. 